\title{
Usulan Metode Distribusi Produk Fast Moving Consumer Goods Pada PT. Pintu Tiga Utama
}

\author{
Maria Amelia S.L ${ }^{1^{\star}}$, Primahasmi Dalulia ${ }^{2}$, \\ ${ }^{12}$ Prodi Teknik Industri,Universitas Merdeka Malang \\ *Korespondensi Penulis, E-mail: primahasmi.dalulia@unmer.ac.id
}

\begin{abstract}
Abstrak
PT. Pintu Tiga Utama merupakan perusahaan distribusi yang bekerja sama dengan Unilever Indonesia, Frisian Flag Indonesia, Fumakilla Nomos, Sinarmas, PZ Cussons dan Unilever Food Solution. Metode exsisting yang digunakan di PT. Pintu Tiga Utama dalam distribusi dibantu menggunakan software Nexus Distribution 6 yang berfungsi untuk menentukan jumlah pemesanan produk ke supplier. Namun dalam penggunaan software ini di PT. Pintu Tiga Utama belum optimal dikarenakan terdapat overstock produk yang diakibatkan tidak sesuai data aktual di gudang. Selain itu, dengan penggunaan software Nexus Distribution 6 PT. Pintu Tiga Utama tidak menentukan jumlah pemesanan optimal, persediaan pengaman dan penjadwalan pemesanan. Dari hasil penelitian, didapatkan metode usulan yang menggunakan Distribution Resource Planning (DRP), Safety Stock, dan Economic Order Quantity (EOQ) yang memiliki kelebihan seperti penjadwalan distribusi yang lebih teratur dan menentukan ukuran pesanan yang ekonomis untuk menghindari overstock produk.
\end{abstract}

Kata kunci: Distribusi, Produk, Pemesanan, Optimal, Supplier,

\section{Pendahuluan}

PT. Pintu Tiga Utama merupakan perusahaan distribusi yang bekerja sama dengan Unilever Indonesia yaitu produk detergen dan produk kecantikan, Frisian Flag Indonesia yaitu produk susu, Fumakilla Nomos yaitu produk anti nyamuk, Sinarmas yaitu produk minyak, PZ Cussons yaitu produk bayi, dan Unilever Food Solution (UFS) yaitu produk makanan. Dengan menerapkan strategi Supply Chain Management, PT. Pintu Tiga Utama dapat mengelola aliran produk dan material dengan baik antara supplier, perusahaan dan distributor.

Produk yang didistribusikan ke ke PT. Pintu Tiga Utama, Sinarmas 21 jenis produk, Unilever 16 jenis produk, UFS 70 jenis produk, Cussons 3 jenis produk dan FFI 79 jenis produk. Supplier yang mendistribusikan jenis produk paling banyak yaitu Sinarmas, UFS dan FFI.

Namun upaya yang dilakukan PT. Pintu Tiga Utama tak jarang mengalami hambatan di bidang pendistribusian barang seperti keterlambatan pengiriman barang yang disebabkan oleh beberapa faktor, seperti faktor kemacetan di jalur darat, adanya komponen barang yang kurang, sering terjadi kerusakan pada truk operasional, dan truk operasional yang belum sesuai dengan kebutuhan. Masalah yang terjadi dalam pendistribusian PT. Pintu Tiga Utama menyebabkan keterlambatan pengiriman dari PT. Pintu Tiga Utama ke konsumen. Dalam kasus yang dihadapi perusahan ini berhubungan dengan saluran distribusi yang digunakan agar unit/produk bisa sampai ke pelanggan tepat waktu dan tepat sasaran. Menurut data historis perusahaan, produk yang sering mengalami keterlambatan adalah produk dari Unilever Indonesia dan Sinarmas (agribusiness and food). Keterlambatan distribusi produk dari PT. Sinarmas terjadi sebesar $25 \%$ dari total pengiriman selama 1 bulan dan Keterlambatan distribusi produk dari PT. Sinarmas terjadi sebesar $42 \%$.

Menurut [1], "Saluran distribusi merupakan kumpulan organisasi yang melakukan kegiatan/proses untuk menyalurkan produk/jasa dari penjual ke pembeli akhir". Tanpa adanya saluran distribusi yang baik, maka service level yang diharapkan/ingin dicapai tidak akan terealisasi. 
Service level merupakan suatu konsep dalam penilaian kepuasan konsumen atas orderan yang tepat waktu dan sesuai dengan jumlah orderan. Service level dipengaruhi oleh faktor rata-rata persediaan, safety stock, dan jumlah barang yang masuk. Selain perhitungan service level juga dapat dihitung tingkat inventory optimum yang mendapatkan service level yang maksimum. Penelitian ini bertujuan untuk mengetahui metode exsisting yang digunakan oleh perusahaan dalam distribusi dari supplier ke customer serta usulan metode distribusi yang sistematis untuk perbaikan metode distribusi eksisting dari perusahaan untuk menurunkan tingkat keterlambatan dari distribusi.

\section{Tinjauan Pustaka}

\subsection{Supply Chain Management}

Menurut [2], Supply Chain Management adalah metode untuk mengelola aliran produk, informasi, dan uang secara terintegrasi yang melibatkan pihak-pihak mulai dari hulu ke hilir yang terdiri dari supplier, pabrik, jaringan distribusi maupun jasa-jasa logistik. Sebuah entitas usaha tidak dapat mencapai potensi penuh dalam hal mengembangkan atau memberikan produk dan layanan tanpa menggunakan wawasan pemasaran untuk membentuk dan memperbaiki tata kelola rantai pasok./Supply Chain [3]

Aliran dalam supply chain sangat berhubungan antar satu dan yang lainnya. Material yang dibutuhkan dalam proses distribusi menjadi hal penting dalam proses distribusi. Material yang dibutuhkan akan dipasok oleh supplier melalui informasi yang akan dikalkulasi kebutuhan dalam pendistribusian oleh bagian PPIC. Informasi yang telah didapat akan diteruskan dibagian Procurement untuk mencari supplier material yang dibutuhkan. Dalam jaringan supply chain informasi mengalir dari hulu ke hilir. Mulai dari material tersebut didapat sampai menjadi produk dan didistribusikan kepada konsumen.

\section{- Rantai Suplai Hulu}

Bagian hulu dalam supply chain meliputi kegiatan dari perusahaan manufaktur dengan para penyalurannya/pemasok. Hubungan para pemasok dengan perusahaan terjalin ketika kebutuhan bahan yang diperlukan untuk proses distribusi. Di dalam rantai suplai hulu, aktivitas yang utama adalah inventory.

\section{- Rantai Suplai Hilir}

Dalam rantai suplai hilir meliputi semua kegiatan yang melibatkan pengiriman produk kepada pelanggan akhir. Di dalam rantai suplai hilir, perhatian diarahkan pada distribusi, pergudangan, transportasi, dan after-sales-service. Pesanan dari konsumen akan didistribusikan kepada agen atau retail untuk dijual kepada konsumen.

Menurut [1], "Saluran distribusi merupakan kumpulan organisasi yang melakukan kegiatan/proses untuk menyalurkan produk/jasa dari penjual ke pembeli akhir". Maka, dapat disimpulkan bahwa saluran distribusi merupakan aliran produk dari produsen ke konsumen. Menurut [2], pada prinsipnya fungsi ini bertujuan untuk menciptakan pelayanan yang tinggi ke pelanggan yang bisa dilihat dari tingkat service level yang dicapai, kecepatan pengiriman, kesempurnaan barang sampai ke tangan pelanggan, serta pelayanan purna jual yang memuaskan. Kegiatan transportasi dan distribusi bisa dilakukan oleh perusahaan manufaktur dengan membentuk bagian distribusi/transportasi tersendiri atau diserahkan ke pihak ketiga. 


\subsection{Ordering Policy}

\subsubsection{Demand forecasting}

Menurut [4], tujuan dari metode forecasting adalah untuk memprediksi komponen permintaan yang sistematis dan memperkirakan komponen acak. Macam-macam metode forecasting.

1. Moving Average

2. Simple Exponential Smoothing

3. Holt's

\subsubsection{Economic Order Quantity (EOQ)}

Menurut [2], model Economic Order Quantity adalah salah satu model sederhana yang bisa digunakan untuk menentukan ukuran pesanan yang ekonomis. Rumus EOQ sebagai berikut : $E O Q=\sqrt{\frac{2 \times C \times D}{P \times F}}$

\subsection{Distribution Resource Planning (DRP)}

Menurut [5], Distribution Resource Planning (DRP) berfungsi untuk menentukan jumlah kebutuhan untuk mengisi kembali inventory pada branch warehouse ( distribution centre ). Pada awalnya konsep DRP diarahkan agar terjadi integrasi bidang produksi dan distribusi. Dengan DRP ini unit usaha memulai penjadwalan distribusi dengan lebih akurat dan pada saat yang sama mencapai stabilitas produksi. Sebagai akibatnya kegiatan distribusi produk dapat memperoleh keuntungan yang besar dalam hal perbaikan customer service, pengurangan persediaan, pengurangan biaya-biaya barang yang usang. Dalam konsep selanjutnya konsep DRP ini dapat diterapkan pada jaringan sistem distribusi antara Central Supply Facility (CSF) dan Distribution Centre (DC) nya. Persediaan yang berlebih merupakan aset negatif bagi perusahaan karena persediaan ini menggunakan tempat penyimpanan yang sangat berharga, mengurangi modal kerja, mengurangi nilai $\mathrm{ROI}$ dan lain sebagainya. Item yang berlebih dan usang sebaiknya dikurangi atau dibuang.

\subsection{Penelitian Terdahulu}

Pada tahun 2009, [6] melakukan penelitian yang berjudul Metode Supply Chain Management Untuk Menganalisis Bullwhip Effect Guna Meningkatkan Efektivitas Sistem Distribusi Produk, dimana Hasil perhitungan nilai variabilitas menunjukan terjadinya bullwhip effect hampir disemua produk yang dikrimkan ke retailer. Kecuali pada produk sekido untuk retailer Sri Ratu Peterongan Semarang, produk sekido untuk retailer Sri Ratu Pemuda Semarang dan produk begaya untuk retailer Mirota Kampus Yogyakarta. Karena masing-masing Retailer tersebut memiliki nilai variansi permintaan sebesar 1,28; 1,$65 ; 1,45$; yang berarti lebih besar dari nilai perbandingan antara fungsi periode dan lead time sebesar 1,18. Dari hasil pengolahan data inventory dengan metode sistem $Q$, diperoleh iterasi terbaik pada iterasi 1 untuk produk Dadung dengan total biaya persediaan Rp. 39.638.737,53. Sedangkan untuk produk Begaya iterasi terbaik pada iterasi 3 dengan total biaya persediaan Rp. 27.924.118,81 dan untuk produk Sekido iterasi terbaik pada iterasi 2 dengan total biaya persediaan sebesar Rp. 52.328.084,57.

Penelitian yang dilakukan oleh [5], menerapkan Distribution Resource Planning, dengan hasil bahwa order policy yang sebaiknya diterapkan adalah Lot-For-Lot untuk distributor Surabaya, Pekalongan, Sidoarjo dan Probolinggo sedangkan untuk distributor Bogor digunakan Economic Order Quantity dengan ukuran pemesanan sebesar 19 unit. Besarnya Safety Stock untuk produk X102 adalah: Surabaya sebanyak 12 unit, Bogor dan Pekalongan sebanyak 5 unit, Sidoarjo sebanyak 2 unit, Probolinggo sebanyak 4 unit dan IKM XYZ sebanyak 24 unit.

Tahun 2009, [7] melakukan penelitian Perencanaan Dan Penjadwalan Aktivitas Distribusi Hasil Perikanan Dengan Menggunakan Distribution Requirement Planning 
(DRP). Distribusi perusahaan selama tahun 2008 sebanyak 146 kali pengiriman kurang teratur dengan biaya Rp. 1.809.172.000,-. Apabila menerapkan metode DRP, distribusi hanya akan dilakukan sebanyak 114 kali secara lebih teratur dengan biaya Rp. 1.693.348.000,-, sehingga terjadi penurunan biaya hingga Rp. 115.824.000,- atau 6.4 $\%$.

\section{Metode Penelitian}

Survei lapangan merupakan tahap awal untuk mengetahui kondisi lapangan dengan melakukan pengamatan secara langsung dan wawancara perwakilan pihak perusahaan. Survei lapangan dilaksanakan di PT. Pintu Tiga Utama Kadipaten yang berada di wilayah Majalengka, Jawa Barat. Dari hasil survei perusahaan diperoleh permasalahan yang berkaitan dengan distrbusi produk Fast Moving Consumer Goods (FMCG) perusahaan. Selanjutnya dilakukan perumusan masalah untuk memberi jawaban dan penyelesaian secara sistematis

Data yang didapatkan pada penelitian ini yaitu data keterlambatan pengiriman produk, data produk supplier, data pembelian customer, data history permintaan produk, dan data inventory produk. Pada proses pengolahan data yang dilakukan adalah melakukan forecast data menggunakan metode Moving Average, Exponensial, dan Holt's Method dengan menggunakan data history permintaan produk dari bulan Februari 2018 - bulan Mei 2019, untuk menemukan peramalan yang terbaik berdasarkan nilai MAD terkecil. Kemudian dilakukan kebijakan dalam melakukan order produk ke supplier (Order Policy) menggunakan metode Economic Order Quantity (EOQ) dengan menggunakan data history permintaan produk dari bulan Februari 2018 - bulan Mei 2019 dan data inventory produk, metode Safety Stock dengan menggunakan data keterlambatan pengiriman produk dan data historis permintaan produk dari bulan Februari 2018 - bulan Mei 2019 , dan metode Distribution Resource Planning (DRP) dengan menggunakan data peramalan MAD terkecil. Analisis data dilakukan terhadap hasil pengolahan metode Moving Average, Exponential, dan Holt's Method dan menggunakan metode Economic Order Quantity (EOQ), Safety Stock, dan Distribution Resource Planning (DRP). Pada tahap ini membahas hasil pengolahan data Service Level Perusahaan dan proses distribusi yang telah diidentifikasi dan ditentukan strategi yang tepat berdasarkan alternatif yang ada.

\section{Pengumpulan Data}

\section{a. Data History Permintaan Produk}

Data history permintaan produk merupakan data permintaan produk dari customer ke PT. Pintu Tiga Utama untuk produk-produk dari supplier tertentu. Data ini akan digunakan dalam menentukan kebutuhan produk di masa depan dengan menggunakan metode demand forecasting. Data history permintaan produk Sinarmas bulan Februari 2018 - bulan Mei 2019 dapat ditunjukkan pada Gambar 1 disajikan trend permintaan dari produk - produk Sinarmas, dimana terlihat kecenderungan sebagian besar permintaan berpola uniform dengan adanya variasi di bulan Februari 2019 - Mei 2019.

Dari beberapa jenis produk Sinarmas produk yang digunakan dalam penelitian ini yaitu Filma, Kunci Mas dan Zoda OWB yang merupakan 3 produk dengan jumlah permintaan produk paling tinggi. 


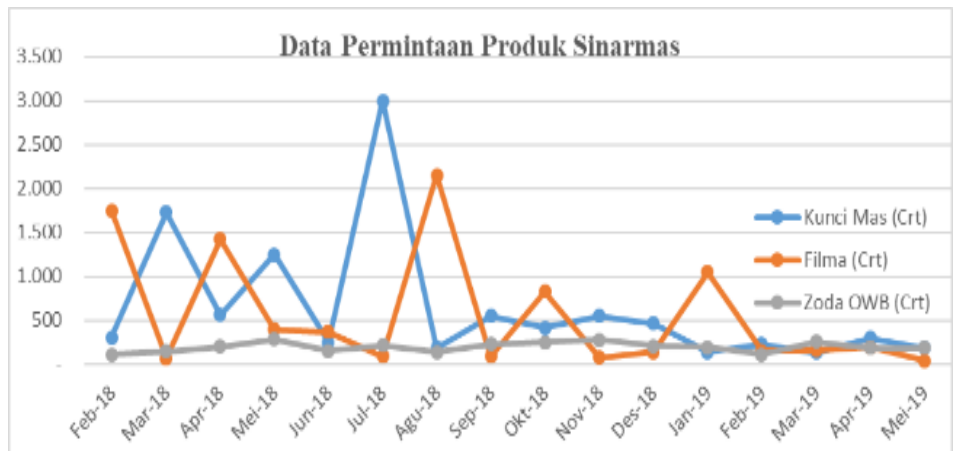

Gambar 4.1. Data permintaan produk Sinarmas

Data history permintaan produk Unilever bulan Februari 2018 - bulan Mei 2019 dapat ditunjukkan pada Gambar 4.2.

Dari beberapa jenis produk Unilever produk yang digunakan dalam penelitian ini yaitu Royco, Bango dan Pepsodent yang merupakan 3 produk dengan jumlah permintaan produk paling tinggi.

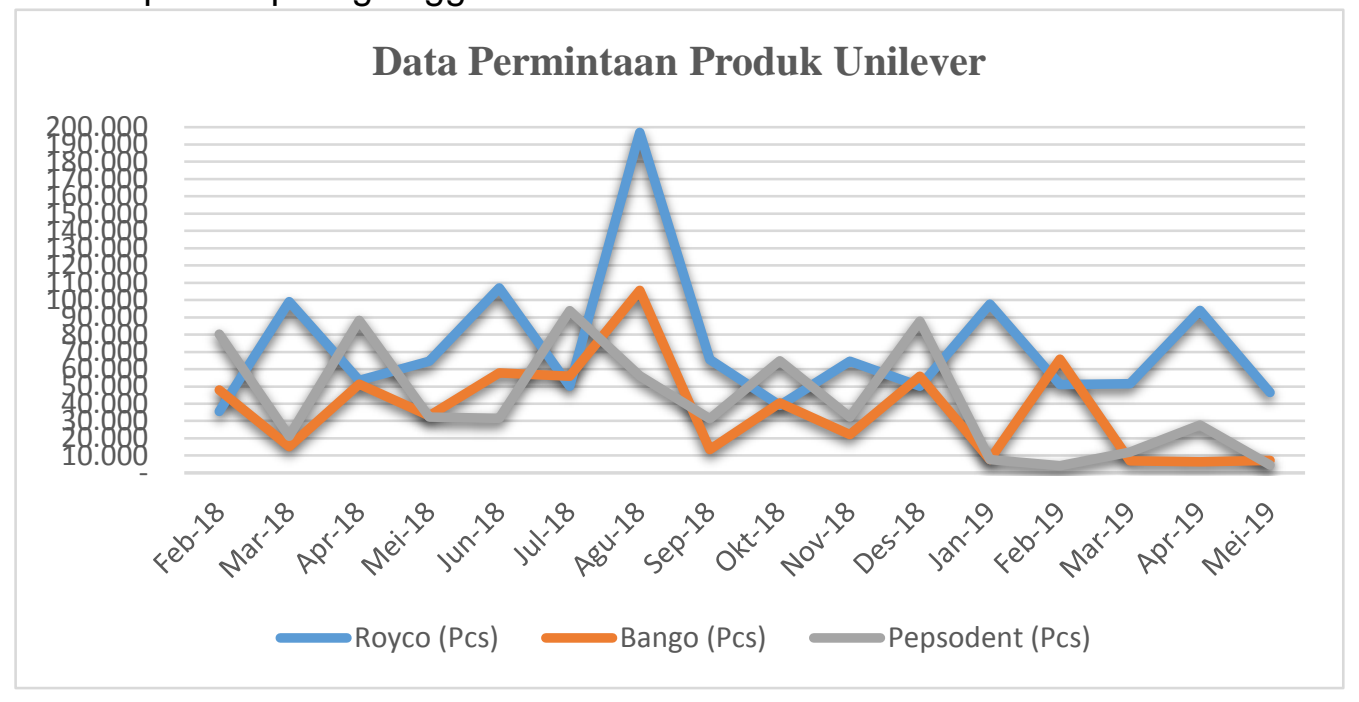

\section{Gambar 4.2. Data Permintaan Produk Unilever}

Pada Gambar 4.2. disajikan trend permintaan dari produk - produk Unilever, dimana terlihat kecenderungan sebagian besar permintaan bervariasi.

\section{b. Data Biaya Pesan Dan Biaya Simpan}

Biaya pesan dan biaya simpan digunakan untuk menentukan total biaya yang ditimbulkan dari pemesanan. Data biaya pemesanan didapatkan dari bagian Internal Finance \& Audit PT. Pintu Tiga Utama yaitu Rp 45.000. Biaya-biaya yang termasuk biaya pemesanan antara lain biaya telpon, biaya cetak PO, dan lain sebagainya.

Data biaya penyimpanan didapatkan $30 \%$ dari harga produk PT. Pintu Tiga Utama. Untuk penjelasan harga produk ditunjukkan pada Tabel 4.1. 
Tabel 4.1. Data harga produk Unilever dan Sinarmas

\begin{tabular}{|c|c|c|r|}
\hline Supplier & Produk & Harga & $\begin{array}{c}\text { Biaya } \\
\text { Simpan }\end{array}$ \\
\hline \multirow{3}{*}{ Unilever } & Royco & Rp7.901 & Rp2.370 \\
\cline { 2 - 4 } & Bango & Rp7.333 & Rp2.200 \\
\cline { 2 - 4 } & Pepsodent & Rp11.420 & Rp3.426 \\
\hline \multirow{3}{*}{ Sinarmas } & Filma & Rp154.250 & Rp46.275 \\
\cline { 2 - 4 } & Kunci Mas & Rp143.332 & Rp43.000 \\
\cline { 2 - 4 } & Zoda OWB & Rp84.000 & Rp25.200 \\
\hline
\end{tabular}

\section{c. Data Safety Stock}

Safety stock digunakan untuk mengatasi fluktuasi demand yang terjadi pada saat lead time pemesanan. Data Demand didapatkan dari permintaan produk bulan mei 2018 - mei 2019, data lead time didapatkan dari waktu pemesanan produk ke supplier sampai dengan waktu kedatangan produk dari supplier ke PT. Pintu Tiga Utama. Data ini digunakan untuk menentukan safety stock, dikarenakan demand dan lead time bervariasi setiap pemesanan produknya. Data demand ditunjukkan pada Tabel 4.2. Lead time rata - rata dari PT. Unilever adalah 3,58 hari dengan standar deviasi 0,79. Sedangkan lead time rata - rata dari PT. Sinarmas adalah 3,75 hari dengan standar deviasi 1,29.

Tabel 4.2. Data demand tahunan (Mei 2018-Mei 2019)

\begin{tabular}{|l|r|r|r|}
\hline Produk & $\begin{array}{r}\text { Total } \\
\text { Demand }\end{array}$ & $\begin{array}{r}\text { Rata-rata } \\
\text { Demand }\end{array}$ & $\begin{array}{c}\text { Stdev } \\
\text { Demand }\end{array}$ \\
\hline Royco & 978.970 & 75.305 & 42.370 \\
\hline Bango & 478.278 & 36.791 & 30.366 \\
\hline Pepsodent & 486.111 & 37.393 & 29.926 \\
\hline Filma & 5.717 & 440 & 599 \\
\hline Kunci Mas & 7.629 & 587 & 784 \\
\hline $\begin{array}{l}\text { Zoda } \\
\text { OWB }\end{array}$ & 2.663 & 205 & 53 \\
\hline
\end{tabular}

\section{Pengolahan Dan Analisis Data}

\subsection{Pengolahan Data}

Pada proses pengolahan data yang dilakukan adalah melakukan forecast data menggunakan metode Moving Average, Exponensial, dan Holt's Method dengan menggunakan data history permintaan produk dari bulan Februari 2018 - bulan Mei 2019, untuk menemukan peramalan yang terbaik berdasarkan nilai MAD terkecil. Kemudian dilakukan kebijakan dalam melakukan order produk ke supplier (Order Policy) menggunakan metode Economic Order Quantity (EOQ) dengan menggunakan data history permintaan produk dari bulan Februari 2018 - bulan Mei 2019 dan data inventory produk , metode Safety Stock dengan menggunakan data keterlambatan pengiriman produk dan data history permintaan produk dari bulan Februari 2018 - bulan Mei 2019 , dan metode Distribution Resource Planning (DRP) dengan menggunakan data peramalan MAD terkecil. Data hasil perhitungan error yang digunakan untuk memilih metode forecast yang terbaik disajikan pada Tabel 5.1 dan 5.2. 
Tabel 5.1. Kesimpulan forecasting dari produk Sinarmas

\begin{tabular}{|c|c|c|c|}
\hline $\begin{array}{c}\text { Metode } \\
\text { forecasting }\end{array}$ & Produk & & ror \\
\hline \multirow{9}{*}{ MA } & \multirow{3}{*}{ Filma } & MSE & 443.892 \\
\hline & & MAD & 415 \\
\hline & & MAPE & 270 \\
\hline & \multirow{3}{*}{$\begin{array}{l}\text { Kunci } \\
\text { Mas }\end{array}$} & MSE & 588.345 \\
\hline & & MAD & 398 \\
\hline & & MAPE & 113 \\
\hline & \multirow{3}{*}{$\begin{array}{l}\text { Zoda } \\
\text { OWB }\end{array}$} & MSE & 3.133 \\
\hline & & MAD & 34 \\
\hline & & MAPE & 20 \\
\hline \multirow{9}{*}{ SES } & \multirow{3}{*}{ Filma } & MSE & 462.814 \\
\hline & & MAD & 589 \\
\hline & & MAPE & 360 \\
\hline & \multirow{3}{*}{$\begin{array}{l}\text { Kunci } \\
\text { Mas }\end{array}$} & MSE & 575.963 \\
\hline & & MAD & 573 \\
\hline & & MAPE & 156 \\
\hline & \multirow{3}{*}{$\begin{array}{l}\text { Zoda } \\
\text { OWB }\end{array}$} & MSE & 3.086 \\
\hline & & MAD & 46 \\
\hline & & MAPE & 27 \\
\hline \multirow{9}{*}{ HOLT'S } & \multirow{3}{*}{ Filma } & MSE & 400.035 \\
\hline & & MAD & 497 \\
\hline & & MAPE & 267 \\
\hline & \multirow{3}{*}{$\begin{array}{c}\text { Kunci } \\
\text { Mas }\end{array}$} & MSE & 504.005 \\
\hline & & MAD & 461 \\
\hline & & MAPE & 108 \\
\hline & \multirow{3}{*}{$\begin{array}{l}\text { Zoda } \\
\text { OWB }\end{array}$} & MSE & 3.192 \\
\hline & & MAD & 49 \\
\hline & & MAPE & 28 \\
\hline
\end{tabular}

Dari metode peramalan produk Sinarmas diatas nilai MAD terkecil dari Filma yaitu berada di Moving Average dengan nilai $M A D=415$, nilai MAD terkecil dari Kunci Mas yaitu berada di Moving Average dengan nilai MAD = 398 dan nilai MAD terkecil dari Zoda OWB yaitu berada di Moving Average dengan nilai MAD $=34$. 
Tabel 5.2. Ringkasan forecasting dari produk Unilever

\begin{tabular}{|c|c|c|c|}
\hline $\begin{array}{c}\text { Metode } \\
\text { forecasting }\end{array}$ & Produk & & Error \\
\hline \multirow{9}{*}{ MA } & \multirow{3}{*}{ Royco } & MSE & 2.610 .046 .343 \\
\hline & & MAD & 31.240 \\
\hline & & MAPE & 44 \\
\hline & \multirow{3}{*}{ Bango } & MSE & 957.408 .140 \\
\hline & & MAD & 20.977 \\
\hline & & MAPE & 135 \\
\hline & \multirow{3}{*}{ Pepsodent } & MSE & 911.740 .470 \\
\hline & & MAD & 25.319 \\
\hline & & MAPE & 150 \\
\hline \multirow{9}{*}{ SES } & \multirow{3}{*}{ Royco } & MSE & 1.649 .342 .097 \\
\hline & & MAD & 31.186 \\
\hline & & MAPE & 46 \\
\hline & \multirow{3}{*}{ Bango } & MSE & 788.478 .863 \\
\hline & & MAD & 24.115 \\
\hline & & MAPE & 164 \\
\hline & \multirow{3}{*}{ Pepsodent } & MSE & 981.065 .734 \\
\hline & & MAD & 28.295 \\
\hline & & MAPE & 205 \\
\hline \multirow{9}{*}{ HOLT'S } & \multirow{3}{*}{ Royco } & MSE & 1.708 .186 .835 \\
\hline & & MAD & 31.318 \\
\hline & & MAPE & 46 \\
\hline & \multirow{3}{*}{ Bango } & MSE & 742.114 .500 \\
\hline & & MAD & 22.478 \\
\hline & & MAPE & 132 \\
\hline & \multirow{3}{*}{ Pepsodent } & MSE & 779.345 .241 \\
\hline & & MAD & 23.872 \\
\hline & & MAPE & 136 \\
\hline
\end{tabular}

Dari metode peramalan produk Unilever diatas nilai MAD terkecil dari Royco yaitu berada di Exponensial dengan nilai $M A D=31.186$, nilai MAD terkecil dari Bango yaitu berada di Moving Average dengan nilai $M A D=20.977$ dan nilai MAD terkecil dari Pepsodent yaitu berada di Holt's Method dengan nilai MAD $=23.872$.

\subsection{Order Policy}

Dalam penelitian Order Policy ini menggunakan metode Economic Order Quantity (EOQ), Safety Stock, Distribution Resource Planning (DRP).

\subsubsection{EOQ}

1. EOQ Sinarmas (Filma)

$$
E O Q=\sqrt{\frac{2 \times C \times D}{P \times F}}=\sqrt{\frac{2 \times 45.000 \times 5.717}{154.250 \times 30 \%}}=106 \text { Unit }
$$


2. EOQ Unilever (Royco)

$$
E O Q=\sqrt{\frac{2 \times C \times D}{P \times F}}=\sqrt{\frac{2 \times 45.000 \times 978.970}{7.901 \times 30 \%}}=6.097 \text { Unit }
$$

Nilai demand didapatkan dari permintaan produk bulan Mei 2018 - Mei 2019, biaya pemesanan didapatkan dari bagian Internal Finance \& Audit PT. Pintu Tiga Utama yaitu Rp 45.000. Biaya penyimpanan didapatkan dari fraksi $30 \%$ harga produk PT. Pintu Tiga Utama, dan harga produk yaitu Sinarmas harga produk per karton dan Unilever harga produk per unit.

\subsubsection{Safety Stock}

Penentuan Safety Stock pada produk-produk PT. Pintu Tiga Utama berdasarkan interaksi antara demand dan lead time. Dimana demand pada produk-produk PT. Pintu Tiga Utama merupakan demand yang bervariasi (variabel) dan lead time yang bervariasi (variabel).Nilai service level adalah nilai yang ditargetkan PT. Pintu Tiga Utama yaitu 95\%.

$$
\text { 1. } \begin{aligned}
S S_{\text {Filma }} & =\mathrm{Z} \times \sqrt{d^{2} \times S l^{2}+l \times S d^{2}} \\
& =1.645 \times \sqrt{440^{2} \times 1.29^{2}+3.75 \times 599^{2}}=2.124 \text { Unit }
\end{aligned}
$$

Pada Tabel 5.3. disajikan hasil perhitungn EOQ dan safety stock dari produk Sinarmas dan Unilever.

Tabel 5.3. Nilai EOQ dan safety stock produk Sinarmas dan Unilever

\begin{tabular}{|c|c|r|r|}
\hline Supplier & Produk & Nilai EOQ & Safety Stock \\
\hline \multirow{3}{*}{ Sinarmas } & Filma & 106 & 2124 \\
\cline { 2 - 4 } & Kunci Mas & 127 & 2791 \\
\cline { 2 - 4 } & Zoda & & \\
& OWB & 98 & 447 \\
\hline \multirow{3}{*}{ Unilever } & Royco & 6097 & 167 \\
\cline { 2 - 4 } & Bango & 4424 & 107 \\
\cline { 2 - 4 } & Pepsodent & 3574 & 105 \\
\hline
\end{tabular}

\subsubsection{Perhitungan TC (Total Ongkos)}

1. TC Sinarmas (Filma)

$$
T C_{b}=\left(\frac{D}{Q}\right) \times C_{b}+\left(\frac{Q}{2}\right) h_{b}=\left(\frac{5.717}{106}\right) \times 45.000+\left(\frac{106}{2}\right) \times 30 \%=\mathrm{Rp} 2.427 .044
$$

Berdasarkan perhitungan diatas nilai total cost produk Filma $\mathrm{Rp}$ 2.427.044, Kunci Mas Rp 2.703.208, Zoda OWB Rp 1.222.821, Royco Rp 7.226.378 , Bango Rp 4.865.607, dan Pepsodent Rp 6.121.128.

Nilai total cost yang paling kecil terdapat pada produk Zoda OWB yaitu

Rp 1.222.821 dipengaruhi oleh demand yang sedikit dan harga produk yang rendah (per karton) dan total cost yang paling besar terdapat pada produk Royco yaitu $\mathrm{Rp} 7.226 .378$ dipengaruhi oleh demand yang besar.

\subsection{Distribution Resource Planning (DRP)}

Pengolahan data diatas menjadi input dalam pengolahan Distribution Resource Planning (DRP). Distribution Resource Planning (DRP) berisikan 6 komponen yaitu Gross Requirement (GR), Schedule Receipt (SR), Project on Hand (PoH), Net 


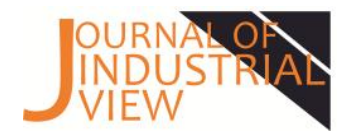

e-ISSN : 2685 - 3159

Requirement (NR), Planned Order Receipt (PORe) dan Planned Order Release (PORI).

Distribution Resource Planning (DRP) dari forecast demand, permintaannya adalah bulanan dengan asumsi 1 bulan 4 minggu kerja dan pola order seminggu sekali, maka order dilakukan setiap awal minggu. Berikut tabel-tabel DRP setiap produk.

Contoh perhitungan Gross Requirement (GR) yaitu Safety Stock + forecast = $2124+135=2.259 / 4=565$.

Data Pengolahan DRP, disajikan pada Tabel 6 sampai Tabel 11.

Tabel 5.4. DRP Filma

\begin{tabular}{|c|c|c|c|c|c|c|c|c|c|c|c|c|c|c|c|c|c|c|c|c|c|c|c|c|c|c|c|c|}
\hline \begin{tabular}{|l} 
Item \\
Lot Size
\end{tabular} & $\begin{array}{c}\text { Filma } \\
25\end{array}$ & \begin{tabular}{|l|} 
LLC \\
LT
\end{tabular} & $\frac{0}{3}$ & PD & 1 & 2 & 3 & 4 & 5 & 6 & 7 & 8 & 9 & 10 & 11 & 12 & 13 & 14 & 15 & 16 & 17 & 18 & 19 & 20 & 21 & 22 & 23 & 24 \\
\hline \multicolumn{4}{|c|}{ Gross Requirement } & & & & 565 & & & & & & 565 & & & & & & & 565 & & & & & & 565 & & \\
\hline \multicolumn{29}{|c|}{ Schedule Receipts } \\
\hline \multicolumn{4}{|c|}{ Project On Hand } & 0 & 1.672 & 1.672 & 1.107 & 1.107 & 1.107 & 1.107 & 1.107 & 1.107 & 542 & 542 & 542 & 542 & 542 & 542 & 542 & 0 & 0 & 0 & 0 & 0 & 0 & 10 & 10 & 10 \\
\hline \multicolumn{4}{|c|}{ Net Requirements } & & & & & & & & & & & & & & & & & 23 & & & & & & 575 & & \\
\hline \multicolumn{4}{|c|}{\begin{tabular}{|l|} 
Planned Order Receipts \\
\end{tabular}} & & & & & & & & & & & & & & & & & 25 & & & & & & 575 & & \\
\hline \multicolumn{4}{|c|}{ Planned Order Release } & & & & & & & & & & & & & & 25 & & & & & & 575 & & & & & \\
\hline
\end{tabular}

\section{Tabel 5.5. DRP Kunci Mas}

\begin{tabular}{|c|c|c|c|c|c|c|c|c|c|c|c|c|c|c|c|c|c|c|c|c|c|c|c|c|c|c|c|c|}
\hline \begin{tabular}{|l} 
Item \\
Lot Size
\end{tabular} & $\begin{array}{c}\text { Kunci Mas } \\
25\end{array}$ & \begin{tabular}{|l|} 
LLC \\
LT \\
\end{tabular} & 0 & PD & 1 & 2 & 3 & 4 & 5 & 6 & 7 & 8 & 9 & 10 & 11 & 12 & 13 & 14 & 15 & 16 & 17 & 18 & 19 & 20 & 21 & 22 & 23 & 24 \\
\hline \multicolumn{4}{|c|}{ Gross Requirement } & & & & & 750 & & & & & & 750 & & & & & & 750 & & & & & & 750 & & \\
\hline \multicolumn{29}{|c|}{ Schedule Receipts } \\
\hline \multicolumn{4}{|c|}{ Project On Hand } & 0 & 807 & 807 & 807 & 57 & 57 & 57 & 57 & 57 & 57 & 0 & 0 & 0 & 0 & 0 & 0 & 0 & 0 & 0 & 0 & 0 & 0 & 0 & 0 & \\
\hline \begin{tabular}{|l} 
Item \\
Lot Size
\end{tabular} & $\frac{\text { Zoda 0WB }}{15}$ & \begin{tabular}{|l} 
LLC \\
LT
\end{tabular} & $\frac{0}{3}$ & PD & 1 & 2 & 3 & 4 & 5 & 6 & 7 & 8 & 9 & 10 & 11 & 12 & 13 & 14 & 15 & 16 & 17 & 18 & 19 & 20 & 21 & 22 & 23 & 24 \\
\hline $\begin{array}{l}\text { PRanlmedur } \\
\text { Gioss Req }\end{array}$ & $\begin{array}{l}\text { ET keledse } \\
\text { rentent }\end{array}$ & & & $\square$ & & & 162 & & & & & & 162 & & & & & & 162 & & & & & & 162 & & & \\
\hline Schedule I & ceipts & & & & & & & & & & & & & & & & & & & & & & & & & & & \\
\hline Project On & & & & 0 & 1.065 & 1.065 & 903 & 903 & 903 & 903 & 903 & 903 & 741 & 741 & 741 & 741 & 741 & 741 & 579 & 579 & 579 & 579 & 579 & 579 & 417 & 417 & 417 & 417 \\
\hline Net Requir & ments & & & & & & & & & & & & & & & & & & & & & & & & & & & \\
\hline Planned 0 & ler Receipts & & & & & & & & & & & & & & & & & & & & & & & & & & & \\
\hline Planned 0 & ler Release & & & & & & & & & & & & & & & & & & & & & & & & & & & \\
\hline
\end{tabular}

Tabel 5.6. DRP Royco

\begin{tabular}{|c|c|c|c|c|c|c|c|c|c|c|c|c|c|c|c|c|c|c|c|c|c|c|c|c|c|c|c|c|}
\hline \begin{tabular}{|l|} 
Item \\
Lot Size \\
\end{tabular} & $\begin{array}{c}\text { Royco } \\
30\end{array}$ & \begin{tabular}{|l|} 
LLC \\
LT \\
\end{tabular} & \begin{tabular}{|l|}
0 \\
3 \\
\end{tabular} & PD & 1 & 2 & 3 & 4 & 5 & 6 & 7 & 8 & 9 & 10 & 11 & 12 & 13 & 14 & 15 & 16 & 17 & 18 & 19 & 20 & 21 & 22 & 23 & 24 \\
\hline Gross Requirement & & & & & & & & 17.778 & & & & & & 17.778 & & & & & & 17.778 & & & & & & 17.778 & & \\
\hline Schedule Receipts & & & & & & & & & & & & & & & & & & & & & & & & & & & & \\
\hline Project On Hand & & & & 0 & 2.087 & 2.087 & 2087 & 29 & 29 & 29 & 29 & 29 & 29 & 11 & 11 & 11 & 11 & 11 & 11 & 23 & 23 & 23 & 23 & 23 & 23 & 35 & 35 & 35 \\
\hline Net Requirements & & & & & & & & 15.691 & & & & & & 17.749 & & & & & & 17.767 & & & & & & 17.755 & & \\
\hline Planned Order Receipts & & & & & & & & 15.720 & & & & & & 17.760 & & & & & & 17.790 & & & & & & 17.790 & & \\
\hline Planned Order Release & & & & & 15.720 & & & & & & 17.760 & & & & & & 17.790 & & & & & & 17.790 & & & & & \\
\hline
\end{tabular}

Tabel 5.7. DRP Bango

\begin{tabular}{|c|c|c|c|c|c|c|c|c|c|c|c|c|c|c|c|c|c|c|c|c|c|c|c|c|c|c|c|c|}
\hline \begin{tabular}{|l} 
Item \\
Lot Size \\
\end{tabular} & $\begin{array}{c}\text { Bango } \\
20 \\
\end{array}$ & \begin{tabular}{|l|} 
LCC \\
LT \\
\end{tabular} & \begin{tabular}{|l|}
0 \\
3 \\
\end{tabular} & PD & 1 & 2 & 3 & 4 & 5 & 6 & 7 & 8 & 9 & 10 & 11 & 12 & 13 & 14 & 15 & 16 & 17 & 18 & 19 & 20 & 21 & 22 & 23 & 24 \\
\hline Gross Requirement & & & & & & & & 5.421 & & & & & & 5.421 & & & & & & 5421 & & & & & & 5421 & & \\
\hline Schedule Receipts & & & & & & & & & & & & & & & & & & & & & & & & & & & & \\
\hline Project On Hand & & & & 0 & 1.260 & 1.260 & 1.260 & 0 & 19 & 19 & 19 & 19 & 19 & 18 & 18 & 18 & 18 & 18 & 18 & 17 & 17 & 17 & 17 & 17 & 17 & 16 & 16 & 16 \\
\hline Net Requirements & & & & & & & & 4.161 & & & & & & 5.402 & & & & & & 5.403 & & & & & & 5.404 & & \\
\hline Planned Order Receipts & & & & & & & & 4.180 & & & & & & 5.420 & & & & & & 5.420 & & & & & & 5.420 & & \\
\hline Planned Order Release & & & & & 4.180 & & & & & & 5.420 & & & & & & 5.420 & & & & & & 5.420 & & & & & \\
\hline
\end{tabular}


Tabel 5.8. DRP Pepsodent

\begin{tabular}{|c|c|c|c|c|c|c|c|c|c|c|c|c|c|c|c|c|c|c|c|c|c|c|c|c|c|c|c|c|}
\hline $\begin{array}{l}\text { them } \\
\text { LotSize } \\
\end{array}$ & $\begin{array}{c}\text { Pepsoctent } \\
20\end{array}$ & \begin{tabular}{|l|} 
LCC \\
LT \\
\end{tabular} & \begin{tabular}{|l|}
0 \\
3 \\
\end{tabular} & PD & 1 & 2 & 3 & 4 & 5 & 6 & 7 & 8 & 9 & 10 & 11 & 12 & 13 & 14 & 15 & 16 & 17 & 18 & 19 & 20 & 21 & 22 & 23 & 24 \\
\hline Cross Requirement & & & & & & & & 3.564 & & & & & & 3.564 & & & & & & 3.564 & & & & & & 3.564 & & \\
\hline Schedule Receipts & & & & & & & & & & & & & & & & & & & & & & & & & & & & \\
\hline \begin{tabular}{|l|} 
Net Requirements \\
\end{tabular} & & & & & & & & 2334 & & & & & & 3.548 & & & & & & 3.552 & & & & & & 3.556 & & \\
\hline Planned Order Receipts & & & & & & & & 2320 & & & & & & 3.560 & & & & & & 3.560 & & & & & & 3.560 & & \\
\hline Planned Order Release & & & & & 2320 & & & & & & 3.560 & & & & & & 3.560 & & & & & & 3.500 & & & & & \\
\hline
\end{tabular}

\section{Kesimpulan}

Berdasarkan dari hasil pengolahan data dan analisis data, maka dapat disimpulkan bahwa :

1. Metode exsisting yang digunakan di PT. Pintu Tiga Utama dalam distribusi dibantu menggunakan software Nexus Distribution 6. Namun dalam penggunaan software ini di PT. Pintu Tiga Utama belum optimal dikarenakan terdapat overstock produk yang diakibatkan tidak sesuai data aktual di gudang. Selain itu, dengan penggunaan software Nexus Distribution 6 PT. Pintu Tiga Utama tidak menentukan jumlah pemesanan optimal, persediaan pengaman dan penjadwalan pemesanan.

2. Usulan metode distribusi yang sistematis untuk perbaikan metode distribusi eksisting di PT. Pintu Tiga Utama yaitu menggunakan Economic Order Quantity (EOQ), Safety Stock, dan Distribution Resource Planning (DRP) agar tidak terjadi overstock produk dan keterlambatan pengiriman produk.

\section{Daftar Pustaka}

[1] Tjiptono, Fandi. (2014). Pemasaran Jasa : Prinsip, Penerapan, dan Penelitian. Andi Offset. Yogyakarta.

[2] Mahendrawathi dan Pujawan. (2010). Supply Chain Management. Edisi 2. Penerbit ANDI.

[3] Kurnia Isnuwardiati, Pudjo Sugito, (2018), Pengaruh Demand Chain Management terhadap Daya Saing. Conference on Innovation and Application of Science and Technology, pp $21-30$

[4] Chopra, Meindl. (2013). Supply Chain Management : Strategy, Planning, \& Operations. Third Edition. Harlow : Pearson Education.

[5] Hidayat, Nurhasanah, Zulkifli. (2013). Perencanaan \& Penjadwalan Distribusi Pakaian Jadi Dengan Metode Distribution Resource Planning. Program Studi Teknik Industri, Fakultas Sains dan Teknologi, Universitas Al Azhar Indonesia.

[6] Parwati, Andrianto. (2009). Metode Supply Chain Management Untuk Menganalisis Bullwhip Effect Guna Meningkatkan Efektivitas Sistem Distribusi Produk. Jurusan Teknik Industri, Institut Sains \& Teknologi, AKPRIND Yogyakarta..

[7] Abdillah. (2009). Perencanaan Dan Penjadwadlan Aktivitas Distribusi Hasil Perikanan Dengan Menggunakan Distribution Requirement Planning (DRP). Jurusan Teknik Industri, Fakultas Teknologi Industri, Universitas Pembangunan Nasional "Veteran" Jatim. 